Meta

Journal des traducteurs

Translators' Journal

\title{
From an Empire to a Nation State: Importing the Concept of Nation into Ottoman/Turkish Thinking
}

\section{Elif Daldeniz}

Volume 59, numéro 1, avril 2014

URI : https://id.erudit.org/iderudit/1026471ar

DOI : https://doi.org/10.7202/1026471ar

Aller au sommaire du numéro

Éditeur(s)

Les Presses de l’Université de Montréal

ISSN

0026-0452 (imprimé)

1492-1421 (numérique)

Découvrir la revue

Citer cet article

Daldeniz, E. (2014). From an Empire to a Nation State: Importing the Concept of Nation into Ottoman/Turkish Thinking. Meta, 59(1), 72-96.

https://doi.org/10.7202/1026471ar

\section{Résumé de l'article}

Les concepts importés dans un contexte cible sont modelés par ce dernier ainsi que par les agents participant au processus. Ces deux facteurs ont un rôle central. Par conséquent, la traduction, que ce soit dans ses dimensions les plus étroites ou les plus vastes, joue un rôle important. L'objectif du présent article est de faire état de résultats de recherche préliminaires sur l'importation du concept de 'nation' dans la culture turque ottomane. Les données proviennent de l'analyse de dictionnaires ainsi que de textes rédigés par des personnalités marquantes du nationalisme turc au cours des dernières décennies de l'Empire ottoman. Nous avons eu recours à des analyses de première main portant sur des textes clés écrits par Yusuf Akçura et Ziya Gökalp, qui étudient, sur la base de sources secondaires, la manière dont d'autres figures importantes ont fait usage du concept de nation. Enfin, l'analyse a également porté sur des traductions. L'étude, qui est liée à une autre recherche portant sur le concept de 'culture', se veut interdisciplinaire et s'appuie, sur le plan des perspectives et des notions, sur la traductologie, ainsi que, pour la méthodologie, sur l'histoire des concepts. Le cadre théorique et la méthodologie sont exposés dans la première partie, tandis que la deuxième partie fait état des résultats et de la discussion.
Ce document est protégé par la loi sur le droit d'auteur. L'utilisation des services d’Érudit (y compris la reproduction) est assujettie à sa politique d'utilisation que vous pouvez consulter en ligne.

https://apropos.erudit.org/fr/usagers/politique-dutilisation/ 


\title{
From an Empire to a Nation State: Importing the Concept of Nation into Ottoman/Turkish Thinking:*
}

\author{
ELIF DALDENIZ \\ Okan University, Istanbul, Turkey \\ elif.daldeniz@okan.edu.tr
}

\section{RÉSUMÉ}

Les concepts importés dans un contexte cible sont modelés par ce dernier ainsi que par les agents participant au processus. Ces deux facteurs ont un rôle central. Par conséquent, la traduction, que ce soit dans ses dimensions les plus étroites ou les plus vastes, joue un rôle important. L'objectif du présent article est de faire état de résultats de recherche préliminaires sur l'importation du concept de 'nation' dans la culture turque ottomane. Les données proviennent de l'analyse de dictionnaires ainsi que de textes rédigés par des personnalités marquantes du nationalisme turc au cours des dernières décennies de l'Empire ottoman. Nous avons eu recours à des analyses de première main portant sur des textes clés écrits par Yusuf Akçura et Ziya Gökalp, qui étudient, sur la base de sources secondaires, la manière dont d'autres figures importantes ont fait usage du concept de nation. Enfin, l'analyse a également porté sur des traductions. L'étude, qui est liée à une autre recherche portant sur le concept de 'culture', se veut interdisciplinaire et s'appuie, sur le plan des perspectives et des notions, sur la traductologie, ainsi que, pour la méthodologie, sur l'histoire des concepts. Le cadre théorique et la méthodologie sont exposés dans la première partie, tandis que la deuxième partie fait état des résultats et de la discussion.

\begin{abstract}
During importation processes of concepts, the target context and the agents involved in these processes are central and shape the imported ideas. Hereby, translation, both in its narrow and broader senses, plays an important role. The aim of this article is to present preliminary research results on the importation process of the concept of nation into the Ottoman/Turkish culture as the target culture. The article provides research results gained from the analysis of dictionaries as well as of texts written by important figures of Turkish nationalism during the last decades of the Ottoman Empire. The research covers first-hand analysis of key texts by Yusuf Akçura and Ziya Gökalp whereby the use of the concept of 'nation' by other key figures are discussed on the basis of secondary sources. The analysis also includes translations. This study, which is linked to a study on the concept of 'culture,' was based on an interdisciplinary approach relying on the perspectives and notions of translation studies and on methodology developed in conceptual history. The theoretical framework and methodology adopted in this study are exposed in the first part, whilst the second part presents and discusses the research results.
\end{abstract}

\section{MOTS-CLÉS/KEYWORDS}

traduction des concepts, histoire des concepts, nation, nationalisme turc conceptual translation, history of concepts, nation, Turkish nationalism 
Strictly speaking, comparative scholarship that aims to cross cultures can do nothing but translate.

(Liu 1995: 1)

With the proclamation of the republic on October 29, 1923, the Ottoman Empire was officially transformed into the Republic of Turkey as a nation state. The proclamation of the republic was the product of a long process during which generations of agents had played an important role. Although the announcement itself was a hallmark in the process of nation building, it was not its end point. Thereafter, the process was pursued eagerly as the official ideology of the new state. One of the driving ideas behind this transformation process was the concept of 'nation,' where the allegiance to the state was radically altered from the allegiance to an empire represented by the Sultan. This concept together with concepts like 'democracy,' 'culture,' 'secularity,' 'positivism,' etc. served as building blocks for the new state. It is legitimate to argue that this transformation involved the translation - both in its broader and narrower senses - of an empire following Western ${ }^{1}$ models: translation as the introduction of structures and models as well as the translation of a wide variety of texts into (Ottoman) Turkish. For example, European laws were translated into (Ottoman) Turkish during the Empire as well as in Republican Turkey, and were put into force with mostly minimum amendments to establish legal structures according to the ones existing in Western Europe. ${ }^{2}$ In the Tanzimat, or "Reorganization" period, beginning with the proclamation of various reforms in 1839, works of European literature started to be translated into Ottoman Turkish (Paker 1998: 578; Berk 2004: 15), whereby new literary genres - amongst which the novel - were introduced into the target system. In the same period, reforms of the education system were considered to be crucial, as will be discussed later. Also during the Republican period, a university reform was designed to transform the existing institutions, and to establish new universities according to the imported models. ${ }^{3}$ In these processes of translation, ideas and theories that were perceived as indispensable for modernization were imported.

The aim of this article is to examine the process of importing one of the key building blocks for the Turkish Republic: the concept of 'nation.' The first part of this article tackles methodological questions regarding the study of concepts from a translational perspective. It outlines the analytical tools and the method used in the research, which is linked to a study on the importation of the concept of 'culture.' In the second part, the preliminary study results are presented and discussed. The concluding part interrogates how these results might contribute to gaining insights into the processes of intercultural exchange. Moreover, interrogating the intercultural transfer of concepts might also result in important findings to open up new fields of research for translation studies.

\section{Theoretical Framework}

At first sight, postcolonial theories might seem to provide a general theoretical framework for the present case since the period discussed in this paper is marked by power differentials between the Ottoman Empire and Western European countries. However, like in the context of interrogating the migration of Roland Barthes' theo- 
ries from French into Turkish (Susam-Sarajeva 2006), postcolonial theories are incompatible for this study due to the following reasons. The Ottoman Empire has been a center of empire itself. Although the Ottoman Empire, and later on Turkey, have come "under profound influence of hegemonic powers economically, politically and culturally" (Susam-Sarajeva 2006: 13), I concur with Susam-Sarajeva that the cases studied within a postcolonial framework do not "resemble those which were not subjected to colonization" (Susam-Sarajeva 2006: 13). Where the researcher is faced with the Turkish modernization process as the general historical and sociopolitical context, this framework fails to account for the local intricacies. Although during the last period of the Ottoman Empire relations with Western European countries were deeply asymmetrical, the Empire's interaction with its European counterparts were not dominated by the latter's interests. In addition, the role of the agents in the former cannot be reduced to passive importers, nor did they share a homogenous identity. Different agents with different interests were involved in shaping the importation processes, as is shown in the case study. Prior to further elaborations on the theoretical framework, a brief explanation of the historical context ${ }^{5}$ is considered necessary.

With the empire as a place of diverse interactions, and due to its vast territory, the Ottomans used to be under the influence of western as well as eastern traditions (Berkes 2002: 36). ${ }^{6}$ However, towards the end of the $15^{\text {th }}$ century, the Empire seems to have lost vivid exchanges with Western Europe (Berkes 2002: 37), a region that underwent in this and the following centuries profound changes paving the way to a new age. The Ottoman Empire started to lose territories in Europe as of the $17^{\text {th }}$ century. This period also marked the beginning of the decline of the Empire that had been conquering European territory from the $14^{\text {th }}$ century onwards. Berkes argues that from the beginning of the $18^{\text {th }}$ century, statesmen and intellectuals started to explain the reasons for the decline of the Empire by the fact that it fell behind the scientific and technological advances in Western Europe (Berkes 2002: 39). It was also at this period that, for the first time, it was announced that changes in the fields of science and technology were essential (Berkes 2002: 40).

Since the first drawbacks were profoundly felt on the battlefield, the first modernization efforts were seen in the field of military during the reign of Sultan Selim III (1761-1808) (Berkes 2002: 96). Apart from the reforms of the Ottoman army, the curriculum of the military school was changed to include new courses whereby French textbooks were translated and put to use for the first time. Moreover, as an important novelty, French was introduced as the first European foreign language in this school (Berkes 2002: 96). However, the teaching of French in this school also fueled major criticism (Berkes 2002: 186), and the uprisings against the reform of the Ottoman army in 1807 hindered its further development. Berkes argues that the school triggered strong resistance since its reformatory potential was soon noticed (Berkes 2002: 98). The uprisings can be interpreted as first signs of resistance to reform and to import from the West. However, this phenomenon of resistance is obviously quite complex and should not be reduced to a scheme of reformers, on the one hand, and traditionalists on the other one, as will be shown.

At the beginning of the $19^{\text {th }}$ century, high ranking officials, bureaucrats, intellectuals and different groupings in society declared that military renewal was not sufficient and profound enough, and that in fact, a complete reorganization of society 
along the models of Western Europe was needed (Berkes 2002: 133-134). The hallmark of these efforts can be seen in the proclamation of an imperial edict, the Gülhane Rescript [Gülhane Hatt-1 Hümayunu], on 3 November 1839. With this proclamation, a period of a number of political and social reforms began, whereby the edict was mainly a charter intending to limit the power of the Sultan compared to the rights of all subjects, regardless of their religious identities (Berkes 2002: 214). The population living in the Empire was not bound to the state on the basis of citizenship, as in a nation state. It was organized according to religious identities, with separate religious and judicial systems applicable according to one's own faith. The uniting principle was the unconditional loyalty to the Sultan, who did not interfere in matters regarding faith or the language spoken by each community. With the edict, not only the relationship between the Sultan and his subjects was limited for the first time, but this relationship was meant to be organized on the basis of equal rights granted to all citizens, regardless of their identity.

These reforms, introduced in the Tanzimat period, as it is widely referred to in Turkish, had a profound impact on education (Berkes 2002: 237). Like during the reign of Selim III, different social groups exerted resistance against the reforms as well as against new institutions established by these reforms. However, contradictory developments were seen even in the same field. I will briefly discuss the field of education as a remarkable example. The first university in its modern sense, and encompassing the faculties of literature, law and medicine, was established on February 20, 1870. However, it was soon closed down one year later due to heavy criticism raised by the Sheikh ul-Islam (Berkes 2002: 238), the highest religious authority in the Ottoman Empire. It is to be noted that, only one year earlier, the first foreign secular secondary school, Lycée Français Galatasaray, had been found. Despite the fact that the Vatican prohibited Catholics to send their children to the school, that the Russian embassy resorted to propaganda to hinder Orthodox Greeks from enrolling their children, and that the Muslim community hesitated (Berkes 2002: 242-243), this institution was successful and was soon followed by other schools, which provided the opportunity of a secular education. As such, these schools filled a vacuum in the Ottoman education system. Whilst the resistance of the Sheikh ul-Islam can be seen as one of the phases of the clash between religious and worldly affairs in the Empire (Berkes 2002: 241), and can be interpreted in a wider context of the clashing interests of the establishment and the reformers, this resistance could not prevent the reform of secondary schooling. If we look closely at the modernization processes in this country, we can detect similar contradictory developments caused by the tensions between clashing interests represented by different groupings. These tensions were not caused only by inner groupings of society, but they were also shaped by different political interests of neighboring countries as well as of countries in Western Europe (Berkes 2002: 120-126). To a certain extent, Western European countries also imposed the perceptions of lack and lag of modernization. They tried to force the enactment of certain laws and trade regulations during the last decades of the Ottoman Empire in order to expand their hegemonic influence and to protect their interests in economic as well as political interactions with the Empire, and later on, with the Republic.

Thus, the Turkish case of modernization as Europeanization was shaped by various interests and perceptions. It is therefore possible to evaluate this act of trans- 
$\mathrm{fer}^{7}$ on the one hand as being triggered and partly enforced by European countries, and on the other, as being pursued by high-ranking officials, and supported by intellectuals and political leaders in the country. Despite their different accentuations, the latter aimed to modernize the Empire and, later on, to create a secular nation state from its remnants. Hereby, it is important to note that Ottoman intellectuals who had lived during the last decades of the Empire were discussing how to "localize and apply" (Kara 1999: 285, translated by the author) European civilization. Thus, a domination model alone does not suffice to explain and understand the Ottoman/ Turkish case. Consequently, this case is exemplary for a receiving culture that was actively involved in the process of importation, trying on the one hand to pursue this importation, and on the other one, to select what exactly is going to be imported, whereby certain groupings in the country tried to exert resistance. ${ }^{8}$

As a result, even though the interactions between these systems happened under asymmetrical power relations leading to classifications under binary oppositions such as weak and strong, importing and exporting, subversive and oppressing, or even resisting and dominating, these oversimplify the complexity of the phenomena and "run the risk of reducing the power relationship between East and West to that of native resistance and Western domination" (Liu 1995: 25). Because of these complexities, the postcolonial theories of translation show some weaknesses in the context of the present study.

Where the researcher's aim is to look on what happens when concepts move across languages and cultures, the context of these movements, the individuals involved and their motivations therein need to be taken into account. Descriptive translation studies (DTS) (Toury 1995) and polysystem theory (Even-Zohar 1997) provide the possibility not only for researching the context, but also for foregrounding the role translation played in the Ottoman Empire during the period in question and later on in the Republican period. Moreover, this framework enables to account for the relationship between the importing and the exporting systems. Where the importation of concepts, models, theories, etc. is done under the heading of 'modernization as westernization' as it has been in this country, the importing system sees the exporting system as a model to aspire to in order to solve problems and weaknesses in the former. Toury's emphasis that a comparative perspective motivates the transfer between the systems is important to note: it is "[...] in view of a corresponding non-gap in another culture that the prospective target culture has reasons to look up to and try to exploit" (Toury 1995: 27). Bearing the above summarized intricacies in mind, it can be concluded that importation often happens due to the existence of a need, a lack (as perceived) in the receiving system (Even-Zohar 1997; 2002; Toury 1995), as it was the case in Turkey. DTS and polysystem theory provide a comprehensive approach to account for the interaction between the systems discussed in this paper. Considering that "the framework provided by the descriptive approach to translation can be usefully extended to cover issues of value and power" (SusamSarajeva 2006: 15), this approach is applied in this study with an awareness of the asymmetrical relations between the involved systems.

The fact that research on the transfer of concepts cannot rely exclusively on tangible translations during the importation process of the concepts, that they may not even exist, causes methodological problems when the point of departure for this kind of research is translation studies. The researcher may search in vain for the 
translation of some (key) texts when studying the movement of concepts across languages and cultures. Political concepts like that of 'nation' in the present study might be introduced via indigenous writing published in newspapers, journals or monographs. The translation of some (key) texts may come much later. During the transformation of the Ottoman Empire into a nation state, 'novel' ideas from Western Europe, in fact the idea of the nation state itself, were introduced by intellectuals, mainly in indigenous articles published in newspapers or journals, as we will see.

However, this lack of translations does not impair the usefulness of the notion of translation for the present research. Contemporary scholars in translation studies foreground the role of translation and of the agents of translation during intercultural exchange. Hereby, each and every act of translation is considered to be an act of transformation involving different temporal and spatial contexts and series of negotiations while the resulting differences are acknowledged. These aspects are crucial when researching the intercultural exchange of concepts. The use of the term translation as an analytical tool in areas well beyond what Jakobson called 'interlingual translation' (Jakobson 2004) and the risks of this usage for the new discipline has been widely discussed. However, as pointed out by Simon, the "broad array of entrypoints into the issues cannot help but contribute to the institutional strength of the field at large, proving its appeal to contemporary thought and social action" (Simon 2009: 210).

However, the transfer of concepts across linguistic and cultural boundaries is an under-researched subject within the discipline. ${ }^{9}$ As it is known, within translation studies, apart from research on terminology, there are discussions primarily on the key concepts (for example, equivalence, fidelity, etc.) of the discipline itself. Since scholars in another discipline - contrastive conceptual history - do conduct research on the flow of ideas and concepts like 'democracy' or 'freedom' or 'the self' between different cultures (see, for example, Howland 2003; Richter 2005), their approaches, and especially the approaches of the German strand of conceptual history, Begriffsgeschichte, have been incorporated in this study.

In fact, an important notion that has been suggested and used by the German tradition of conceptual history has been used in the research framework: the notion of basic concepts. As said previously, this article is not interested in a discussion on terminology, but aims instead to interrogate the concept of 'nation' in the (Ottoman) Turkish language from a translational perspective. Hereby, this concept has been specifically chosen because it is considered to be one of the building blocks in the transformation of the Ottoman Empire to Turkey as a nation state. In this sense, 'nation' is regarded as a basic concept in the discipline conceptual history. According to one of its founders and prominent forerunners, Reinhart Koselleck, a concept becomes a basic concept when it is considered indispensable, by different agents in a particular socio-historical context, "to expressing their distinctive experiences, interests, and party-political programs" (Koselleck 2011: 32). As this differentiation is crucial for the present study, and since conceptual history offers a comprehensive perspective when dealing with (basic) concepts, analytical tools of this discipline have been incorporated in the research framework. Although the approaches in conceptual history have been outlined elsewhere in Turkish (Daldeniz 2010), their important notions for the present study will also be discussed briefly here, since the same interdisciplinary approach was used. 
The case study presented in this paper shows how agents of different generations emphasized different accentuations of the concept of 'nation' when importing it from Western European systems. As will be discussed later, Hobsbawm draws attention to the different conceptualizations of nation in various European cultures shaped by their specific sociopolitical circumstances (Hobsbawm 2010). This variety in meaning is considered to be a characteristic feature of basic concepts studied in conceptual history. Koselleck emphasizes that "a word becomes a concept when a single word is needed that contains - and is indispensable for articulating - the full range of meanings derived from a given sociopolitical context" (Koselleck 2011: 19). He further concludes that a "word may have several possible meanings, but a concept combines in itself an abundance of meanings. Thus, a concept may be clear, but it must be ambiguous" (Koselleck 2011: 20). Although this conclusion may not be surprising for translators and scholars of translation studies, the fact that researchers in conceptual history approach concepts from this perspective is important to note and enables a comprehensive comparison.

Apart from basic concepts, another of Koselleck's notions has proved useful when interrogating the transfer of concepts: triggering concepts. He points out that while some concepts evolved with the usage of a specific word in time, some words are invented and then deliberately used to create, to trigger a concept (Koselleck 2002: 38-39). When the transfer of certain concepts from one culture to another is at stake, the differentiation of triggering concepts provides an important analytical tool. Concepts that may have been "basic concepts" in Koselleck's category in the source system necessarily become "triggering concepts" for the target system when they are transferred to the latter. On the other hand, concepts that can be identified as triggering concepts in the source system at a given time may appear to be basic concepts from the target's perspective, as is shown in the present study.

Koselleck further claims that it is the usage that changes, and not the words. Thus, although the word itself remains the same, the concept it refers to may change since life is under constant change. Koselleck (2002) draws attention to the fact that we use concepts to make and collect experiences in the world out there; creating concepts is essential for the human being, since without concepts he or she is not able to experience anything; however, since life is changing constantly, concepts also change and are often disputed, different conceptualizations occurring as a response to certain historical events. The findings of this study provide excellent examples in this regard. However, the Turkish context also shows that we have to re-consider the assumption that words do not change. As of the end of the $19^{\text {th }}$ century, the Turkish language has undergone a rapid transformation triggered by efforts to purify and vernacularize it. These efforts reached a climax during the first centuries of Republican Turkey, when language planning was on the state agenda, changing the script from Arabic into Latin and supporting purification of the language from loanwords of Perso-Arabic origin. ${ }^{10}$ We may therefore speak of different discourses in the Turkish Language (Paker 1997: 43): pure Turkish (propagated by the language reform following the establishment of the Republic), the conservative reactionary Turkish immersed with Ottoman words of Perso-Arabic origin, or a more liberal stance mainly from the 1980s onwards. This more recent positioning uses both well-established and commonly accepted words of so-called Turkish origin, as well as words from the Ottoman language, and loan words from mainly Western European languages. Thus, 
in the Turkish case, unlike in Western European languages for example, the words used to denote the concepts do change whereby these changes are embedded into ideological structures. It is therefore of the utmost importance to notice that the preference of a word over another may signal an ideological stance. Since these preferences are embedded into specific contexts, the lexical changes may also signal different associations, in fact disputes about the content of the concept in question.

In order to trace the use of concepts, Koselleck (2002: 45-47) makes the following distinction within the sources to be used in the research

- Group 1: letters, newspapers;

- Group 2: dictionaries, encyclopedia;

- Group 3: classical texts of thinkers, intellectuals.

Whereas the first group includes sources written for daily and instant use, the second group includes publications that incorporate different temporal layers and that are normative. Thus, the researchers are able to do empirical studies and look for repetitions, inventions (Koselleck 2002: 45-47). The third group is comprised of texts that incorporate a claim of truth not affected with the passing of time (Koselleck 2002: 47). Since it is emphasized that any research focusing on the development of concepts should be diachronic as well as synchronic in order to trace important ruptures and changes in the past, and in order to interrogate the uses in the present, the above mentioned sources classified into three categories offer both diachronic as well as synchronic perspectives.

However, during the research tracing the concept of 'culture' in the Turkish language, it is revealed that a different evaluation of these categories as introduced by Koselleck is required for the Turkish case (Daldeniz 2010: 104). It is not always possible to make neat separations between the sources. For example, especially during the last era of the Ottoman Empire, many intellectuals, in fact agents, published articles in newspapers or magazines that were then compiled and published as books without a detailed editorial involvement. Bearing that in mind, the present study on the concept of 'nation' covers all three sources. In addition, the research includes, in fact tries to verify, the existence or non-existence of a further source: translations.

The above outlined analytical tools and approaches developed in conceptual history therefore constitute a sound basis when the researcher wants to study the migration of concepts across languages and cultures. However, the overall framework to start with should be based on a holistic perspective regarding the transfer and translation processes involved in these flows. This perspective necessarily includes awareness that transfer and translation processes are complex phenomena resulting inevitably in differences between the source and target contexts involved, and encompassing transformation. It goes without saying that contemporary translation studies have fundamentally contributed to raise awareness in this regard. Some researchers in contrastive conceptual history resort to contemporary translation theories, especially postcolonial translation theories, when they want to analyze the migration of Western concepts like 'the self,' 'freedom' or 'democracy' into cultures in the East.

The research by Richter tracing the flow of concepts like 'liberty' and 'democracy' into the Chinese political discourse can be given as an example (Richter 2005). The points of departure for Richter's research are stated as follows: "What happens when attempts are made to translate the basic political concepts of one society, phrased in 
natural language, to another society with an altogether different history, set of institutions and religions, political culture, and language?" (Richter 2005: 10). These questions are also fundamental for the present study. In order to adopt a more holistic perspective, Richter indicates that following Howland (2003), he benefitted from postcolonial translation theories (Richter 2005: 14) enabling him to account for asymmetrical power relations within intercultural communication and simultaneously defying a normative approach to translation and transfer. According to Richter, contrastive conceptual history should be based on a framework on similar lines (2005: 15). However, it is still not possible to conclude that a systematic interdisciplinary relationship with contemporary translation studies exists in these efforts. Thus, interdisciplinary research from the perspective of translation studies might enhance efforts in this direction.

Finally, one main difference between research in conceptual history and this study has to be emphasized: scholars in this discipline try to investigate the semantic development of concepts in time, thereby focusing especially on semantic transformations and ruptures. But the focus of this study is the initial period where the concept has been introduced into the target system. Due to this focus, the term transfer is not used, in Even-Zohar's sense, since the period in question does not allow for a discussion on whether a full transfer has taken place or not. This question can be answered when the historical perspective is much broader.

\section{From 'millets' in the Ottoman Empire to 'nation' in Turkey}

As indicated above, the concept of 'nation' was not understood in a uniform manner in the source cultures with which the Ottomans were in touch. Hobsbawm claims that different conceptions existed for different populations in Europe. For the process of importation discussed in this paper, the French and German usages are important. Hobsbawm emphasizes that citizenship and mass participation were important components of the French conceptualization (Hobsbawm 2010: 19). The spoken language or ethnicity was not a criterion of nationality as perceived in France, but "the body of citizens whose collective sovereignty constituted them a state which was their political expression" (Hobsbawm 2010: 18-19). On the other hand, for the Germans, especially for the nationalists, language was seen as the indicator of nationality (Hobsbawm 2010: 22). According to Hobsbawm, one of the reasons behind these differentiations was the role of national languages: whilst for the French, the language was "an administrative convenience or a means of unifying state-wide communication" (Hobsbawm 2010: 102-103), the language "was the only thing that made" the Germans (Hobsbawm 2010: 103). We will see that these two different conceptions will appeal to different generations of Ottoman intellectuals who were involved in the process of importing the concept.

Hobsbawm traced the word nation (nacion) in Romance languages as well as in German and in Dutch. He points out that "the modern sense of the word is no older than the eighteenth century" (Hobsbawm 2010: 3). During the course of the $19^{\text {th }}$ century, the concept started to be used in the sense we are familiar with today. We should therefore "accept that in its modern and basically political sense the concept nation is historically very young” (Hobsbawm 2010: 18). Although it might be considered a "very young" concept in the cultures of Western Europe in the $19^{\text {th }}$ century, for the 
agents who took active part in the transformation of the Ottoman Empire into a nation state, this concept was considered as a basic (political) concept that paved the way for the successful nation states in Europe. Thus it seemed indispensable for the target system.

When importation of new items into the target lexical system is at stake, these two options are pointed out by Toury: "[T]he introduction of new lexical items, or new uses of old ones" (1995: 207). When we look at what happened in the Turkish system, we come across two words that are used to denote 'nation': millet and ulus. The former is a word of Arabic origin that was already in use in the Ottoman language. The latter was coined in the $20^{\text {th }}$ century from Turkic languages. Both words and their derivatives are also used in contemporary Turkish. Originally coming from Arabic, where it was used mainly to denote religion and religious communities, millet was a word used in Ottoman times to refer to the different religious groupings in the Empire. As pointed out by Berk, "in the Ottoman Empire, beginning with the fifteenth century, it came to be applied to the organized and legally recognized religious communities" (2004: 33). This usage is also consistent with its Arabic origin. If we look it up in the dictionaries used in this research, we notice entries like the following: Arabic religion, religious sect, religious community, sharia (Nişanyan 2007: 324; Özön 1987: 537; Ayverdi 2008: 2100; see Appendix 2). ${ }^{11}$

At the beginning of the $20^{\text {th }}$ century, the word millet seems to have lost its religious connotation and has started to denote 'nation' in the modern sense (Nişanyan 2007: 324; Ayverdi 2008: 2100). In fact, some dictionaries mention that the word millet was used as the counterpart for the French word nation as of the beginning of the 20 $0^{\text {th }}$ century (Nişanyan 2007: 324; Özon 1987: 537; Ayverdi 2008: 2100). It should be noted that Ayverdi's Kubbealtı Lugatı specifically indicates that, in its modern sense, the word millet denotes 'nation' only in the Turkish language, and not in Arabic as the language of incorporation (Ayverdi 2008: 2001). ${ }^{12}$ Also other forms of the word were developed in the Turkish language only, for example, milliyet [nationality] or millî [national] (Ayverdi 2008: 2100).

From the entries in the dictionaries, we can conclude that, originally, millet was used for the different religious groupings in the Ottoman society. This fact is also confirmed by many scholars, who write, even in their English publications, about the millets in the Ottoman Empire (for example, Niyazi Berkes, Şerif Mardin or François Georgeon). The entries further indicated that, as of the end of the $19^{\text {th }}$ century, the word millet was separated from its religious connotation and was used as the counterpart for nation in the French language. This information is making an explicit reference to the fact that the new usage has been initiated by the efforts to import the novel concept 'nation' into Turkish. Accordingly, a translational relationship is established and confirmed by these entries. ${ }^{13}$

Following the language reform, the word ulus was coined to denote 'nation.' The following entries are worth noticing:

(1) Ulus. Nomad tribes, clans, a Turcoman tribe; $[\mathrm{xx} / \mathrm{b}]$ millet (as a counterpart of the French word nation // Mongolian community of clans, people, nation, state, country, city. $\sim$ Tü uluş [vii+ Uy] city, country, homeland, *although it was originally a word in the Turkic language, it has been re-imported from the Mongolian language.

(Nişanyan 2007: 496; translated by the author) 
(2) Ulus. i. From old Turkish uluş was imported as ulus to Mongolian language; as from the Mongolian invasions it became widespread in Turkish and then forgotten; it has been used after the language reform. 1. nation. 2. clan, community, tribe.

(Ayverdi 2008: 3277; translated by author)

It is important to note that following the language reform and the purification efforts, the word chosen to denote 'nation' was the word ulus, a Turkish word originally denoting a Turcoman tribe. This word seems to have been re-imported into Turkish via the Mongolian language. Thus, the target system has made use of both aforementioned options indicated by Toury (1995). However, it should be underlined that the target system did not introduce a new lexical item during the initial period of importation. The introduction of the word ulus was a consequence of language planning and purification in the Republican period.

Although this paper focuses on the period of importation, it is useful to keep in mind some information concerning the contemporary uses since these triggered the research questions. If we look at bilingual dictionaries published in the last twenty years, we can see that millet is (mostly) the first entry followed by ulus (except for the French-Turkish dictionary), as shown in Table 1.

\section{TABLE 1}

\section{Entries related to the concept of 'nation' in English-, German-, French-Turkish bilingual} dictionaries

\begin{tabular}{|c|c|}
\hline $\begin{array}{l}\text { nation i. Millet, ulus; budun, kavim. [nation; race, clan, tribe] } \\
\text { national i. Milli, ulusal, millete ait [belonging to the nation]; } \\
\text { yurttaş, vatandaş (citizen] } \\
\text { nationality. Millet; milliyet; vatandaşlık [citizenship]; milli } \\
\text { özellikler (national properties) }\end{array}$ & $\begin{array}{l}\text { Avery, Bezmez et al. 1998: } 649 \\
\text { (English-Turkish Dictionary, see } \\
\text { Appendix 2) }\end{array}$ \\
\hline $\begin{array}{l}\text { nation f millet, ulus; -al [nation] milli, ulusal } \\
\text { [national] -ität milliyet; (Staatsangehörigkeit) vatandaşlik } \\
\text { [citizenship] }\end{array}$ & $\begin{array}{l}\text { Steuerwald 1988: } 396 \text { (German- } \\
\text { Turkish Dictionary, see } \\
\text { Appendix 2) }\end{array}$ \\
\hline $\begin{array}{l}\text { nation 1. ulus, }{ }^{\circ} \text { millet [nation]. 2. Kamu, toplum, topluluk } \\
\text { [public, society, community]. } 3 \text { Puta tapan topluluklar } \\
\text { (eskimiştir) [pagan (old usage)] } \\
\text { national,e s. 1. Ulusal, ' millî [national]. 2. Yurttaşlar [citizens]. } \\
\text { nationalité 1. Ulus topluluğu [community of a nation]. 2. Ulusal } \\
\text { özellik [national properties]. 3. uyrukluk [nationality] }\end{array}$ & $\begin{array}{l}\text { Saraç 1989: } 934 \text { (French-Turkish } \\
\text { Dictionary, see Appendix 2) }\end{array}$ \\
\hline
\end{tabular}

${ }^{\circ}$ words used prior to the language reform

Dictionaries, which account for the second category of the sources named by Koselleck (2011), were the starting point for this study. The dictionaries used here provide a wider time span than the period focused on in this article. However, since the findings in the dictionaries provide a general framework, they were discussed before analyzing indigenous texts written by important figures during the importation period of the concept of 'nation.' Before focusing on the usages in concrete texts, I would like to draw attention to the usage of another word for the concept 'nation' in Ottoman Turkish by some Islamist intellectuals: kavm. The first entry in the Ottoman Turkish-Turkish dictionary (Özön 1987) indicates that this word denotes 'a group of people,' whereas in the second entry, it is stated that it means a group of people to which a prophet was sent (Özön 1987: 426). Although not appearing in the 
bilingual dictionaries as a counterpart, it should be noted that this word was used by a relatively small group towards the end of the $19^{\text {th }}$ century. Following the reign of Abdülhamit II (1876-1909), when a movement of Arabism started to gain influence among Islamist intellectuals (Berkes 2002: 436), the words kavm and kavmiyet were used to denote 'nation' and 'nationalism,' respectively. According to Berkes, this movement reached a climax with the publication of the book Islam'da dava-yı kavmiyet [The Cause of Nationalism in Islam] by Ahmet Naim (Berkes 2002: 436). Berkes further claims that this book means "the declaration of a holy war against nationalism" in the Empire (2002: 436, translated by the author). Naim is said to have deliberately used the word kavmiyet as a counterpart for the French word nationalisme since according to him, the use of the word milliyet in this sense by Turkish nationalists was not correct. He openly criticized one of its prominent leaders in particular, Ziya Gökalp, for distorting the meaning of the word millet in the Arabic language (Kara 1999: 291-296). Being an influential intellectual and - after the proclamation of the Republic - a faculty member of Istanbul University, Ahmet Naim was an important figure in the Islamist movement during the last years of the Empire and the first decades of Republican Turkey. Although it opposed the idea of nationalism per se (Berkes 2002: 436), his choice of the Arabic word kavm - which is also used in modern Arabic to refer to 'nation' - is important to note. The said book by Ahmet Naim was not included in this study since he is not among those figures that shaped the conceptualization of nationalism and nationhood in Turkey. In addition, the preference of the word kavm over millet (or their derivatives) needs to be discussed within the framework of ideological schematizations of the thinkers and intellectuals of the time. Since this article has another focus, this aspect will not be further elaborated.

The study analyzed texts written by key figures promoting nationalism. Key texts written by important figures are sources that are listed in Koselleck's third category. The uses of the concept 'nation' by key figures in the first stage, i.e., Şinasi, Sadık Rifat Paşa and Namık Kemal, will be discussed by relying mainly on Şerif Mardin's The Genesis of Young Ottoman Thought: A Study in the Modernization of Turkish Political Ideas (Mardin 2000). Mardin overtly expresses one of the aims of his book as follows:

It may be said, then, that the second aim of this study is to recapture and describe the process by which certain Western political concepts were introduced into Turkey even earlier than the quarter of the nineteenth century and became part of the Turkish intellectual patrimony. (Mardin 2000: 6)

On the other hand, in addition to secondary sources, the study does cover first-hand analysis of key texts written by two members of the next generation of thinkers who were the forerunners of Turkish nationalism: Ziya Gökalp and Yusuf Akçura.

\subsection{The Ottoman Nation}

As pointed out by Şerif Mardin, "[o]ne of the contributions of the Gülhane Rescript was an appeal to 'all subjects' of the Ottoman Empire to band together" (Mardin 2000: 173). It was also at this period that the conception of a single Ottoman nation appeared. "The new term 'millet' [...] begins to appear in the last years of Mahmud's [Mahmud II] reign to express this idea" (Mardin 2000: 174). Mardin also draws attention to the fact that one purpose in drafting this Rescript had been to establish "the 
basis for the eventual creation of an Ottoman nation in which subjects would benefit from identical civil rights, automatically conferred with citizenship and not dependent of religious affiliation" (Mardin 2000: 14).

Sadık Rifat Paşa (1807-1857), an Ottoman bureaucrat and diplomat, is said to be one of the first Ottomans to use the word millet as the equivalent to the French word nation (Mardin 2000: 189). Until that date, the word had had the connotation of a "religious group," as indicated above. Mardin emphasizes that Sadık Rifat Paşa "[...] made such new expressions as 'the interests of the millet' [...], the 'servants of the millet' (Mardin 2000: 189-190). Sadık Rıfat Paşa was as such trying to trigger solidarity among the subjects of the Sultan by creating common interests and a common identity. Also another figure that was influential during this period, the poet Şinasi (1824-1871), ${ }^{14}$ is said to have used the word millet in a similar sense. Mardin gives the following examples:

Şinasi [...] was also the first Ottoman thinker to add a new dimension to the generally felt concern for the salvation of the Ottoman Empire by his wide use of the word "millet," with the connotation of the French word "nation." This term appears quite often in his poetry and articles. Such phrases as "your presence in the heart of the nation is a divine miracle" and his reference to Reşid Paşa as the savior of the "nation" or the "Great Ottoman Nation" are illustrations of this new context in which the word was used. (Mardin 2000: 273-274)

According to Mardin, Şinasi "familiarized Turkish intellectuals with literary, social, and political conceptions current in Europe in the middle of the nineteenth century" (Mardin 2000: 252). Mardin clearly associates this new usage of the word millet by Şinasi as well as by Sadık Rifat Paşa with the French word nation, conceptualizing an identity based on citizenship. This can be interpreted as the manifestation of efforts to trigger this conceptualization in the thinking of the people living in the Ottoman Empire in order to find ways to resist the dissolution of the Empire.

Trained in the Translation Bureau of Customs, and then of the Porte (Mardin 2000: 285) like Şinası, Namık Kemal is another important figure of the first generation. He is considered to be the first modern political theorist of Turkey (Mardin 2000: 285). According to Mardin, Kemal "introduced into Turkey certain key political concepts which affected subsequent generations of Turkish thinkers" (2000: 285). Hereby, Kemal tried to reconcile modern Western concepts with the facts of the Ottoman Empire. Considering that Ottoman society used to be organized according to the "millets system," i.e., the organization of the society according to religious affiliations, Kemal was looking for ways to construct an identity encompassing the populations of the Ottoman Empire. Thus, Kemal conceptualized the Ottoman nation beyond religious and ethnic identities. We may say that Kemal was favoring a harmonious symbiosis of ethnically and religiously different populations (Mardin 2000: 330). Crucially, this new identity was meant to help rescue the Empire. Like Şinasi and Sadık Rıfat Paşa, Kemal used the word millet when writing about the Ottoman nation. However, he still continued to use this word in its former religious connotation as well (Mardin 2000: 287). His use of this word both in the sense of nation as well as in its former religious connotation shows that new uses of old lexical items go hand in hand with former established usage.

Although various publications on modernization in the Ottoman Empire and in Turkey contend that nationalism in general, and the idea of a nation in particular, 
have been incorporated from Western European sources, it is very difficult to clearly establish Western European intellectual mentorship. Şerif Mardin points out that "most of the thinkers of the early Tanzimat fail to indicate European mentorship, and their references to Western political thinkers are almost inexistent" (Mardin 2000: 7). Moreover, "[a]s no single important treatise on politics was published by the Young Ottomans, the sources that we have to rely on here are ones that are usually considered 'occasional,' such as newspaper collections and pamphlets" (Mardin 2000: 9). The non-existence of a "single treatise" is important to note, since it shows that during the first stage the concept was imported via indigenous writing appearing in publications for daily and instant use.

The conception of an Ottoman nation was not established by the end of the $19^{\text {th }}$ century so that the allegiance on the basis of religion was still predominant. Separatist movements, especially in the European parts of the Empire, resulted in several declarations of independence by the 1870s. Since Ottoman intellectuals saw the idea of an Ottoman nation [Osmanlı milleti] above the different religious groupings - the millets - in the Empire as an umbrella identity, the disappointment was shattering when this notion seemed not to be appealing to various communities of the Empire. It was in the aftermath of this disappointment and the rise of nationalism among Western and Eastern European states that the idea of a "Turkish nation" encompassing mainly the Muslim communities of the Empire gained popularity.

During this last era of the Ottoman Empire, journals played a decisive role in spreading as well as discussing the idea of nationalism that paved the way to the Turkish nation state. According to Arai, journals published by different groups propagating Turkish nationalism are the best sources to comprehend this movement as a whole as well as the differentiations between these groups (Arai 2008: 20-21). As a result, also for the present study, which aims to enlighten the role translation played in the construction of the concept of 'nation' in the Turkish thinking, these journals are valuable sources.

\subsection{A rescue idea: Turkish nationalism}

The following journals were published in the 1910s in the Ottoman Empire: Türk Derneği, Genç Kalemler, Türk Yurdu, Türk Ocă̆ı, İslâm Mecmuası (Arai 2008: 21). These journals aimed to spread the idea of Turkish nationalism as the only way to rescue what remained from the Empire. If we go through these journals, we come across, amongst others, the same names that are indicated either in the editorial board and/or as the contributors to the journals: Namık Kemal, Yusuf Akçura, Ziya Gökalp, Fuat Köprülü, Ali Canip, Ömer Seyfettin, Mehmet Emin (Arai 2008: 23-143). This study analyzed these journals to determine the translations therein, since an excursion into the history of concepts often looks for translations of key texts. ${ }^{15}$ The analysis revealed that translations constituted only a small part of the articles and contributions published in these journals. The percentages are indicated in Appendix 1.

Among these translations, only one is relevant for the present research since the rest comprises translations of literary works or texts related to other subjects than nationalism. P. Risal is indicated as the author of this text that is entitled Les Turcs a la recherche d'une âme nationale [The Turks in search of a national soul, translated by the author]. It was published in several subsequent volumes of the journal Türk 
Yurdu [Turkish Homeland]. Only the initials (T.Y.) of the translator are printed at the end of each published part of this text. It is known that Yusuf Akçura was using these initials in the journal as its editor (Arai 2008: 102). Since its content is directly related to the concept of 'nation,' this text will be analyzed in the subsequent paragraphs together with the foreword and epilogue written by the editor who is indicated again by the said initials. ${ }^{16}$

It should be noted that this analysis does not include a comparative perspective taking into account the source text since it could not be identified.

However, before focusing on Risal's article, the journal Türk Yurdu will be introduced in order to contextualize the article. This journal was published by the Türk Yurdu Cemiyeti [Turkish Homeland Society] from November 1911 until 1918 (Özden 1998: $\mathrm{XIV}^{17}$ ). Yusuf Akçura was one of the founders of this society (Özden 1998: XII; Arai 1998: $\mathrm{xxx}^{18}$ ). Arai further mentions that, like Akçura, who migrated from Russia to the Ottoman Empire, other migrants from Russia were also active in this journal (Arai 1998: xxx). Yusuf Akçura states that the journal was published by the Türk Yurdu Cemiyeti to enhance mainly the development of the Ottoman intelligentsia (Arai 1998: Xxx). Moreover, it aimed at promoting a Turkish national spirit among Ottoman Turks (Özden 1998: XIII).

Analyzing and contextualizing the said journals, Arai does not provide any information as to the author P. Risal. The first part of the translation of this article appears in volume 21 of the first year of the journal. It was published with a short foreword written by the editor. The remaining parts were published in the volumes 22 to 26 , and 28. Following the last part of the article in volume 28, a brief epilogue is added. The reason for publishing Risal's article in the first year of the journal is explained in the foreword. The author is said to have a deep knowledge in the history of ideas of the Turkish people. It is further argued that articles written about Turkish people were mostly biased, whereas this text is claimed to be an exception. Moreover, the editor thanks the author for writing positively about the journal Türk Yurdu and the editor. In the epilogue, following a brief note mentioning that the article by Risal came to an end, the reader is informed that some "ideas that were not well comprehended" (Akçura 1998: 70, translated by the author) ${ }^{19}$ were discussed in a rather arbitrary manner by Risal. This comment can be seen as a clear attempt of the editor to distance himself from the article's author.

In the article, Risal informs the readers about the historical developments leading to the rise of Turkish nationalism in the Ottoman Empire. Risal also comments on the agents of the nationalist movement. Briefly, the author draws attention to the fact that the nationalist movement finally reached the Turkish population of the Empire. Risal claims that this should be seen as a reaction against nationalisms and separatist upheavals of other ethnic and religious groupings that were living for centuries under the rule of the Sultan. The author further discusses the interval of the Ottomanist movement during the Young Turk era as a response against the first upheavals in the Empire. Risal further argues that the millets system of the Ottoman Empire had to be abandoned since "there are no nations [milletler ${ }^{20}$ but one nation [millet]" (Risal 1998: 366, translated by the author) ${ }^{21}$. Risal finally appreciates the Turkish nationalist movement following the era of the Young Turks, the nationalist constitutionalist movement during the previous period. He concludes with some positive remarks about the Türk Yurdu and Yusuf Akçura. 
The translator becomes visible with five footnotes. Two of them concern lexical choices. However, in the remaining three, the translator tries (again) to distance himself from the arguments put forward by Risal. In the second footnote, he ascertains that he "translated exactly the words by Mr. P. Risal" (Risal 1998: 384, translated by the author) and further comments that he is not in a position to evaluate whether the opinion raised by the latter is correct or not. In the third and fourth footnotes, the translator signals that the claims put forward by Risal might be exaggerations or not representing the truth.

Considering that the article began to be published in 1911, it should be highlighted that the translator does not write the French counterpart in brackets when the word millet is used for the first time in the article. On the other hand, this is done when other words are used for the first time: internationalisme, exploitation, anticléricalisme, principe (Risal 1998: 68). This shows that the translator considers that the word millet is clearly associated with the French counterpart nation.

As indicated above, during the efforts for modernizing the empire under Mahmud II, the word millet was used in a new sense to trigger a unifying concept of identity beyond religious distinctions. Thus the word millet can be given as a typical example for a word that was injected with a new meaning. The article can be read as an exemplary text showing the shift from the concept of 'millet' in the Ottoman language and thinking to the modern conception of 'nation,' i.e., millet in the singular form. Thus, like in the texts by Kemal, the old and new usages of the word appear next to each other.

Whilst Namık Kemal was the first important modern Turkish political theorist, Ziya Gökalp and Türk Yurdu's editor Yusuf Akçura are the "indisputable leaders of the national movement born during the last years of the Ottoman Empire and the first decades of the Turkish Republic" (Georgeon 2006: 91). Gökalp and Akçura belong to the generation who followed Namik Kemal and his contemporaries, and who played a decisive role in pursuing Turkish nationalism and conceptualizing the Turkish nation. One important means to support the spread of their ideas was the above indicated journals so that it is not surprising that their positions in these journals shaped their content. Like Kemal, they lived after the proclamation of the Rescript of 1839 and were acquainted with French. They both had the opportunity to pay visits to Europe. Yusuf Akçura even spent several years in France (Georgeon 2006: 92-93).

Regarding the conception of nationalism between these two generations, there is one important difference: whereas the former was still convinced that the Empire encompassing an Ottoman nation could be rescued, and continued to emphasize an Ottoman identity, the younger generations opted for Turkish nationalism since they witnessed the inevitable decline of the Empire. Although there were major differences between the other two figures, Ziya Gökalp and Yusuf Akçura, the things they shared should be noted:

1. They were members of the movement of opposition against the Sultan Abdülhamid.

2. Following the revolution of the Young Turks, they played important roles in intellectual and political movements of their time.

3. They were supporters of the new regime after the founding of the Turkish Republic.

4. Both were members of the Turkish Grand National Assembly. 
As for the concept of 'nation' by Gökalp, it can be roughly said that from 1909 until 1918, the religious component (that is, Islam) of this concept became less and less important, and a secular understanding was more and more emphasized. Whilst in former times Gökalp was using the expressions Türk kavmi [Turkish race/nation] when talking of the Turkish/Muslim component within the Ottoman nation, for which he used the expression Osmanl milleti [Ottoman nation], later he started to use the word millet when he was referring to the former, and dropped the usage of the word kavm (Arai 2008: 79; see note 18). ${ }^{22}$ In fact, around the year 1918, Gökalp started to use and to accentuate the expression Türk milleti [Turkish nation] to propagate Turkish nationalism (Arai 2008: 79; see note 18). Thus, there seems to be a deliberate choice of millet over kavm in Gökalp, and not a random usage as claimed by Ahmet Naim. The following texts in Turkish, which are also available in their English translations, have been analyzed: The Ideal of Nationalism, National Language, What is a Nation, Is Turkey a Modern Nation (Gökalp 1959).

In trying to define the components of the concept, Gökalp stressed the linguistic and cultural component. According to him, all people who speak the same language belong to the nation (Gökalp 1959: 77). However, Gökalp also emphasizes that "nationality is not determined by language alone but also by religion" (1959: 78, translated by Niyazi Berkes). In his article titled What is a nation, Gökalp discusses various theories of nationality in Turkey: 1 . The racist theory, which equals nation and race. 2 . The ethnicists' theory, which equals nation with an ethnic group. 3. Those who believe in the primacy of geographical factors. 4. Ottomanists. 5. Pan-Islamists. 6. Believers of a voluntary association with a nation. Looking for a common ground, Gökalp asked these questions: "What kind of unifying force is there that is superior to and dominant over, racial, ethnic, geographic, political and volitional forces? Sociology teaches us that this unifying force lies in education and culture, in other words the community of sentiments" (Gökalp 1959: 136, translated by Niyazi Berkes). We can conclude that the nationality and nation Gökalp was propagating in his academic writings was a conception beyond race, ethnicity, and religion. According to him, this concept could be disseminated via education and culture. It is clear that Gökalp was resorting to the idea of a nation as an up-to-date concept in his time: "Today the West as well as the East show unmistakably that our age is the Age of Nations. The most powerful force over the mind of this age is the ideal of nationalism" (Gökalp 1959: 72, translated by Niyazi Berkes).

Apart from many articles published in journals, where he often was also the editor as above indicated, the other key figure in Turkish nationalism, Yusuf Akçura, published also pamphlets and books where he propagated his views (Georgeon 1986: 159-164). In fact, his pamphlet $\ddot{U} c ̧$ Tarz-ı Siyaset [Three ways of politics] ${ }^{23}$ is considered to be one of the key texts of pan-Turkism (Georgeon 1986: 37). According to Georgeon, the interaction with western thinking with which he was intensively in touch during his years in Paris (1900-1903) can be revealed in this book (Georgeon 1986: 30). Here, Akçura is elaborating on three movements in the Ottoman Empire: Ottomanism, pan-Islamism and pan-Turkism (Georgeon 1986: 35). Among these, Akçura takes the side of the pan-Turkist movement. In the text, the components of 'nation' are stated as follows: language, race, traditions and religion of the Turks scattered all over the world (Georgeon 1986: 40). 
Following this list of components, Georgeon concludes that Akçura was more in favor of the German or Slavic concept of 'nation' (Georgeon 1986: 40). In fact, Georgeon claims that Akçura's Üç Tarz-i Siyaset is a text clearly showing the transition from the French conception of 'nation' as prevalent during the Tanzimat period "to the German or Slavic understanding of nation" (Georgeon 1986: 40, translated by the author). However, although the ethnic aspect is stated as one of the components, Turkism was meant to save the 'nation' in this project. Nevertheless, it should be emphasized that according to him, other ethnicities were not just groupings to be tolerated in the nation state. He propagated that their rights should be accepted and defended (Georgeon 1986: 40). It should be noted, however, that contrary to Ziya Gökalp's, Akçura's conception is emphasizing race and ethnicity.

In another of his books, Muâsır Avrupa'da Siyasî ve İçtimầ Fikirler ve Fikrî Cereyânlar [Political and Social Ideas and Movements], which was published much later (1923), ${ }^{24}$ Akçura is discussing European key political and social ideas and concepts, amongst which the concept of 'nation' (Akçura 2000). In 1923, Westernization as Europeanization had a past of at least 85 years in Turkey. This book is a remarkable example of an effort to discuss new concepts within the context of a target culture. Introducing Western European concepts, Akçura finds himself in the position of a translator who is trying to find equivalents for the concepts of the source language. Since the non-existence of similar concepts is seen as one of the main shortcomings of the Empire and the reasons for its decline, Akçura is one of the agents - one of the most prominent - who wants to contribute to the foundation of these concepts in the target culture. He signals new usages in quotation marks, and additionally puts the terms in the foreign language in brackets. Although published in 1923, it is interesting to see that Akçura used the words millet [nation] and milliyet [nationality] in quotation marks, whereas he had not followed the same course a decade earlier when translating Risal. While trying to discuss the ideas of 'nation' and 'nationality,' he sometimes writes the French counterparts in brackets: "'milliyet fikri (idée de nationalité),' 'milliyetin mebde'i (principe de nationalité)"' (Akçura 2000: 28). We should keep in mind that this book was published by the Grand National Assembly of the new Republic, a nation state that was recently established in Turkey. Akçura's course of action in this book shows that the transfer of concepts into a target culture requires renewed efforts and a long process.

\section{Concluding Remarks}

Although it might be considered as a "very young" concept for the system from which it was imported, for the intellectuals and leaders during the last decades of the Ottoman Empire the idea of 'nation' seemed of the utmost importance: one that could help to save the remaining territories of the Empire. Thus, looking from the perspective of importation, the concept of 'nation' was considered as a basic concept in the exporting system that should be triggered in the target system.

Whereas for the first generation nationhood was constructed around the allegiance to a state, in fact the Empire, the next generation propagated a quite different conceptualization accentuating (Turkish) language and culture. We may roughly say that there has been a shift from the French conceptualization to the German understanding of nation. Although there are differences between the conceptions of Gökalp 
and Akçura as the leading figures of the second generation, it is possible to say that the conception during the rise of Turkish nationalism stressed (national) culture, language and ethnicity as foregrounded by the German conceptualization. Thus, it has to be pointed out that unlike the statements in the dictionaries or encyclopedias, the word millet was not exclusively considered a counterpart to the French concept 'nation.' In the last decades of the Ottoman Empire and the first decades of the Turkish Republic, millet was more than just citizenship and allegiance to a state. It comprised other components, amongst which the competence of the Turkish language. Hence, the purification efforts and vernacularization of the language to build up a national language that was meant to become the basis of Turkish identity in the Republic. This different conceptualization of nation is in line with the nationalism of 1880-1914 in Europe wherein the ethno-linguistic component becomes more and more prominent (Hobsbawm 2010: 102). As such it differs from the French conception based on citizenship and mass participation as discussed previously. However, it would be wrong to conclude that the conception of nation in the second generation is identical with the German one. Although there has been a shift to the latter, the concept is shaped by the local agents' distinctive experiences and interests and by the specific circumstances of the target system. The entries in the dictionaries signaling only the connection to the French language seem to disregard the complexity of the concept of 'nation' in the source, as well as in the target languages, and inevitably reduce its semantic field. Nevertheless, the translational relationship established in the dictionaries is important to note and serves as a clue for further research.

Hobsbawm claims that the "excursus Begrifftgeschichte is not easy, partly because, [...] contemporaries were too unselfconscious about their use of such words..." (Hobsbawm 2010: 18). With regard to the use of the word millet, we may say that it was consistently used as the counterpart for nation in Western European languages to trigger nationhood in Turkey. However, as indicated above, what was perceived as the components of this nation changed remarkably from one generation to the next. Although the use of the word millet to encompass a new meaning started well before Yusuf Akçura, the fact that he was still using this word in quotation marks in 1923 is a sign of the need to mark the (still) novel usage of the already existing word. Having said that, the extensive uses of this word by different important figures, especially by a person like Ziya Gökalp, contributed to its establishment in the Turkish language. In fact, Berkes claims that Gökalp was quite conscious and consistent about the use of specific words or terms (Gökalp 1959: 15). As the founder of sociology in Turkey, it is said that he was quite careful in his usage of specific words and terms in order to introduce certain concepts in the Turkish thinking (Gökalp 1959: 15).

Both generations of Turkish agents of nationalism opted for the use of an existing lexical item in the target language. With their comprehensive efforts to explain and discuss the concept in their numerous writings, they contributed to its importation into in the target system, thereby shaping its content. Hereby, one may argue that a familiar term was preferred to ensure a smooth transition into the content of the novel concept. ${ }^{25}$ And journals played an important role to disseminate the idea since all agents were active as contributors and/or editors of influential journals. The research revealed that the majority of the articles published in these journals were 
written by local agents. Although the agents tried to disseminate the idea of the nation and of nationalism mostly in their own writings, it is legitimate to claim that they were simultaneously acting as translators. They made the new usage of the word millet transparent by including words/expressions in the source languages in brackets, establishing a translational link. These efforts show that the translation of concepts from the source culture to the target culture is not seen as "an unproblematic proposition" (Chakrabarty 2000: 17).

And here research investigating the movement of concepts across languages and culture may contribute to an understanding of these interactions, transformations and changes. Research along similar lines may help raise consciousness and promote intercultural communication without falling into the trap of making the differences absolute. Moreover, tracing the incorporation of concepts from one culture to another is rewarding since it provides valuable insights as to the contemporary concepts we use in our daily lives, encounter in public discourse, come across in academic literature or are commissioned to translate. Thus, the intercultural exchange of concepts offers a rich and interesting area of study for translation scholars, especially in countries like Turkey. ${ }^{26}$

\section{NOTES}

* The present article is published posthumously. For this reason, it was not possible to proceed to the usual verifications of the proofs by the author. However, the author has been able to provide the modifications requested by the anonymous referees.

1. Since this article focuses on the post-Tanzimat period of the Ottoman Empire, which was marked by Westernization/Europeanization efforts as clearly spoken out in public discourse in the Empire, the use of the concept 'West' refers to the Ottoman perception of Western European countries with regard to their relations with the Ottoman Empire.

2. For the reception of European laws in Turkey, see Hirsch (1981) and Bozkurt (1996). For a general discussion, see Berkes (1998). For the role of translation in the construction of a new legal repertoire, see Daldeniz (forthcoming).

3. For a detailed account, see Berk Albachten (2010).

4. For a discussion of the preliminary results of the research on the concept of 'culture' as well as of the issue of methodology, see Daldeniz 2010.

5. Within the scope of this article, only those developments that are important to contextualize the discussions in this paper can be mentioned. Hereby, the specific historical circumstances of Turkish nationalism will be discussed in the next sections.

6. Berkes' groundbreaking book The Development of Secularism in Turkey was published by McGill University in 1964 and it was reprinted in 1998 by Routledge. This publication is included in the bibliography provided in note 8 . However, reference is made to the latest edition of this book in Turkish which was published for the first time in 1978 (Berkes 1978).

The latest edition in Turkish has been prepared on the basis of Berkes' own notes made on the previously published Turkish text and included posthumously in Berkes (2002). As pointed out by the editor of the revised version published in 2002, the Turkish version cannot be labeled as a translation of the English edition since the Turkish and the English texts "are two different books" (Kuyaş 2002: 8).

7. Transfer, in this article, is used in a sense broader than Even-Zohar's use, since Even-Zohar uses this concept to refer to cases where an integration with the target culture, i.e., the localization of the need for the imported good, has been achieved (Even-Zohar 2002: 169). However, importation is used in Even-Zohar's sense (Even-Zohar 2002).

8. For detailed accounts, see for example: Lewis (1961), Mardin (1962), Berkes (1998), Shaw and Shaw (1977), Zürcher (1993), Kasaba (2008).

Among the mentioned sources, Berkes and Mardin were relied upon: Berkes discusses comprehensively the modernization processes in the Ottoman Empire and Republican Turkey, starting with the earliest efforts in the Empire. Thereby, he focuses on another important concept of the 
modernization process in this country: secularization. Mardin provides valuable insights as to the introduction of the concept of 'nation' in its modern sense during the $19^{\text {th }}$ century in Turkey.

9. The symposium on the translation of concepts organized by the Department of Translation and Interpreting Studies of the Boğaziçi University on 14-15 November 2005 can be given as an example for opening up interdisciplinary research on the translation of concepts in Turkey. Papers presented by Özlem Eraydın-Virtanen (2005) and Ismail Kaplan (2005) interrogated the transfer of diverse political concepts into Turkish thinking.

Eraydin-Virtanen, Özlem (2005): Avrupa'da Ortak Bir Siyaset Dili Oluşturulması, Anahtar Siyasi Kavramlar ve Çeviri [Key Political Concepts, Translation and Creation of a Modern Political European Language], unpublished. (Kavramlar Çevrildikçe [Symposium on the translation of concepts], Istanbul, 14-15 November 2005).

Kaplan, İsmail (2005): Sermaye ve Emek Kavramlarının Türkçe’deki Serüveni [The Adventure of the Concepts of Capital and Labour in Turkish], unpublished. (Kavramlar Çevrildikçe [Symposium on the translation of concepts], Istanbul, 14-15 November 2005).

10. For details, see Brendemoen (1990).

11. All the dictionaries used for the research are listed in Appendix 2.

12. In fact, the Arabic language uses another word for nationalism: el-Kavmiyyetu'l-Arabiyye [Arabic nationalism]. The word kavmiyet was used in Ottoman Turkish by a small group of Islamist intellectuals to refer to nationalism, as will be shown and discussed later.

13. The establishment of a translational relationship was also found in the study on the importation of the concept 'culture' into Turkish thinking. See Daldeniz 2010.

14. The birth year of the poet is not exactly determined. The years 1826 and 1827 are also found when searching for biographical information.

15. As an exemplary publication, see the article by Ulrich Ricken on the history of the concept of 'enlightenment' in German and French (Ricken 2002). In this article, Ricken analyzes the French translation of Ernst Cassirer's Philosophie der Aufklärung [Philosophy of Enlightenment].

16. The transliteration of this text by Tekın into the Latin alphabet has been used for the analysis. All of the first volumes published between 1911-1918 have been transliterated and published by Tutibay Yayınları. Türk Yurdu was published with interruptions after the proclamation of the Republic, whereby new volumes have appeared since 1987.

17. Özden, Mehmet (1998): Türk Yurdu Üzerine [About Türk Yurdu] Türk Yurdu. Istanbul: Türk Ocakları Tutibay Yayınevi, xıII-XIV.

18. Arai, Masami (1998): Devlet ve Toplum Arasında Türk Yurdu Dergisine Yeni Bir Yaklaşım [A New Approach to the Journal Türk Yurdu between State and Society]. (Translated by Kemal Kahraman) In: Türk Yurdu. Istanbul: Türk Ocakları Tutibay Yayınevi, XXIX-XLI.

19. Akçura, Yusuf (1998): Epilogue. In: Murat Şefkatli, ed. Türk Yurdu. (Transliterated by Arslan Tekın) Istanbul: Türk Ocakları Tutibay Yayınevi, 70.

20. The suffix -ler indicates plural in Turkish.

21. Risal, P. (1998): Türkler Bir Rûh-I Millî Arryorlar [The Turks in search of a national spirit]. (Translated by Yusuf Akçura and transliterated by Arslan Tekın) Türk Yurdu. Istanbul: Türk Ocakları Tutibay Yayınevi, (21):350-352; (22):365-367; (23):384-385; (24):406-409; (25):21-23; (26):42-45; (28):68-70.

22. I am indebted to my colleague Yesim Tükel Kılıç for drawing my attention to footnote 104 in Arai (2008), where the author discusses this important detail.

23. This article was published for the first time in the Journal Türk, No. 24, in Cairo in 1904. Thereafter, it was published as a pamphlet in 1907 in Cairo, and in 1912 in Istanbul (Georgeon 1986: 160).

24. This book was first published in 1923 by the Publication House of the Grand Assembly of Turkey.

25. I thank the anonymous reader for bringing this option to my attention.

26. I am grateful to Bilge Daldeniz for her comments on this paper.

27. Despite the fact that no translator's name was mentioned, it has been verified that the texts written by these authors were translated. The names of the authors and the translators appear as they have been printed in Arai (2008).

28. The volume and number of the journal are indicated in brackets.

29. The question mark was put by Arai. 


\section{REFERENCES}

AkÇURA, Yusuf (2000): Muâsır Avrupa'da Siyasî ve İçtimaî Fikirler ve Fikrî Cereyânlar [Political and Social Ideas and Movements]. (Edited and transliterated by Adem EFE) Istanbul: Yeni Zamanlar Yayınları.

Arai, Masami (2008): Jön Türk Dönemi Türk Milliyetçiliği. (Translated by Tansel Demirel) Istanbul: İletişism Yayınları.

BERK, Özlem (2004): Translation and Westernisation in Turkey from the 1840s to the 1980s. Istanbul: Ege Yayınları.

Berk Albachten, Özlem (2010): Exile as translation and transformation in early Republican Turkey. Translation Studies. 3(2):132-148.

Berkes, Niyazi (1978): Türkiye'de Çağdaşlaşma, Istanbul: Doğu-Batı Yayınları.

Berkes, Niyazi (1998): The Development of Secularism in Turkey. New York: Routledge.

Berkes, Niyazi (2002): Türkiye'de Çağdaşlaşma [Modernization in Turkey]. Edited by Ahmet KuYAş. Istanbul: Yapı Kredi Yayınları.

Bozkurt, Gülnihal (1996): Batı Hukukunun Türkiye'de Benimsenmesi. Osmanlı Devleti'nden Türkiye Cumhuriyeti'ne Respesiyon Süreci (1839-1939) [The Adoption of Western Law in Turkey. The Process of Reception from the Ottoman Empire until the Turkish Republic (18391939)]. Ankara: Türk Tarih Kurumu Basımevi.

Brendemoen, Bernt (1990): The Turkish language reform and language policy in Turkey. In: György Hazari, ed. Handbuch der Türkischen Sprachwissenschaft. Wiesbaden: Otto Harrassowitz, 454-493.

Chakrabarty, Dipesh (2000): Provincializing Europe. Postcolonial Thought and Historical Difference. Princeton: Princeton University Press.

Daldenız, Elif (2010): Kavramların Yolculuğu: Kültür Kavramının Türkçedeki Serüvenini Çeviribilimsel Bakışla Sorgulamak [Travelling Concepts: Interrogating the Travel of the Concept Culture in the Turkish Language from the Perspectives of Translation Studies]. Alman Dili ve Edebiyatı Dergisi Studien zur Deutschen Sprache und Literatur. 1(23):83-115.

DalDENIZ, Elif (forthcoming): The Effect Of Globalization on a Specialized Field: Insights from the World of Patents in Turkey. In: Saliha Paker, John Milton and Şehnaz TahirGürÇAĞLAR, eds. Translation in Turkey. Amsterdam/Philadelphia: John Benjamins.

Even-Zohar, Itamar (1997): Polysystem Theory (revised version). Visited on 17 March 2003, $<$ http://www.tau.ac.il/-itamarez/papers/ps-th-r.htm>.

Even-Zohar, Itamar (2002): The Making of Culture Repertoire and the Role of Transfer. In: Saliha PAKer, ed. Translations: (Re)shaping of Literature and Culture. Istanbul: Boğaziçi University Press, 166-174.

Georgeon, François (1986): Türk Milliyetçiliğinin Kökenleri - Yusuf Akçura - (1876-1935) [The Sources of Turkish Nationalism - Yusuf Akçura - (1876-1935)]. (Translated by Alev ER) Ankara: Yurt Yayınları.

GEORGEON, François (2006): Osmanlı-Türk Modernleşmesi (1900-1930) [Ottoman-Turkish Modernization (1900-1930)]. (Translated by Ali Berktay) Istanbul: Yapı Kredi Yayınları.

GöкаLp, Ziya (1959): Turkish Nationalism and Western Civilization Selected Essays of Ziya Gökalp. (Translated and edited by Niyazi Berkes) London: Ruskin House George Allen and Unwin Ltd.

Hirsch, Ernst (1981): Rezeption als sozialer Prozeß Erläutert am Beispiel der Türkei. Berlin: Duncker \& Humboldt.

Hobsbawm, Eric J. (2010): Nations and Nationalism since 1780: Programme, Myth, Reality. $17^{\text {th }}$ ed. Cambridge: Cambridge University Press.

Howland, Douglas (2003): The Predicament of Ideas in Culture: Translation and Historiography. History and Theory. 43(1):45-60.

JakoвSON, Roman (2004): On linguistic aspects of translation. In: Lawrence Venuti, ed. The Translation Studies Reader. $2^{\text {nd }}$ ed. London/New York: Routledge, 138-143.

KarA, İsmail (1999): Felsefe ve Tefelsüf - Türkiye'de Felsefe Dili Niçin Yok. Cogito. 19:284-311. 
Kasaba, Reşat (2008): The Cambridge History of Turkey: Volume 4. Turkey in the Modern World. Cambridge: Cambridge University Press.

KoselLeck, Reinhart (2002): Hinweise auf die temporalen Strukturen begriffsgeschichtlichen Wandels. In: Hans Erich BöDECKER, ed. Begriffsgeschichte, Diskursgeschichte, Metapherngeschichte. Göttingen: Wallstein Verlag, 29-48.

Koselleck, Reinhart (2011): Introduction and Prefaces to the Geschichtliche Grundbegriffe. (Translated by Michaela Richter) Contributions to the History of Concepts. 6(1):1-37.

KuYAş, Ahmet (2002): Yayına Hazırlayanın Önsözü [Foreword of the Editor]. In: Niyazi BERKes. Türkiye'de Çağdaşlaşma. Istanbul: Yapı Kredi Yayınları.

Lewis, Bernard (1961): The Emergence of Modern Turkey. London: Oxford University Press.

Liu, Lydia H. (1995): Translingual Practice Literature, National Culture, and Translated Modernity-China, 1900-1937. Stanford: Stanford University Press.

Mardin, Şerif (1962): The Genesis of Young Ottoman Thought: A Study in the Modernization of Turkish Political Ideas. Princeton: Princeton University Press.

Mardin, Şerif (2000): The Genesis of Young Ottoman Thought: A Study in the Modernization of Turkish Political Ideas. Syracuse: Syracuse University Press.

PAKer, Saliha (1997): A Historical Perspective on the Diversity of Discourses in Turkish As a Target Language. In: Hasan AnAmur, ed. Hasan-Âli Yücel Anma Kitabı, Çeviri: Ekinler ve Zamanlar Kavşă̆ı [In Memoriam Hasan-Âli Yücel. Translation at the Crossroads of Cultures and Period]. Istanbul: Yıldız Teknik Üniversitesi, 43-50.

PAKer, Saliha (1998): Turkish Tradition. In: Mona BAKER, ed. Routledge Encyclopedia of Translation Studies. London/New York: Routledge, 571-582.

Richter, Melvin (2005): More than a Two-way Traffic Analyzing, Translating, and Comparing Political Concepts from Other Cultures. Contributions to the history of concepts. 1(1):7-20.

Ricken, Ulrich (2002): Zum Verhältnis vergleichender Begriffsgeschichte und vergleichende Lexikologie. In: Hans Erich BöDECKER, ed. Begriffsgeschichte, Diskursgeschichte Metapherngeschichte. Göttingen: Wallstein Verlag, 49-72.

SHAW, Stanford Jay and SHAW, Ezel Kural (1977): History of the Ottoman Empire and Modern Turkey: Volume II: Reform, Revolution, and Republic: The Rise of Modern Turkey, 1808-1956. Cambridge: Cambridge University Press.

Simon, Sherry (2009): Response. Translation Studies Forum. 2(2):208-213.

Susam-SARAJeva, Şebnem (2006): Theories on the Move - Translations's Role in the Travels of Literary Theory. Amsterdam: Rodopi.

Toury, Gideon (1995): Descriptive Translation Studies and Beyond. Amsterdam/Philadelphia: John Benjamins.

ZüRCHER, Eric (1993): A Modern History. London: I.B. Tauris. 


\section{APPENDICES}

Appendix 1 - Translated articles in journals supporting turkish nationalism

\begin{tabular}{|c|c|c|c|c|}
\hline $\begin{array}{l}\text { Name of the } \\
\text { journal }\end{array}$ & $\begin{array}{l}\text { Number of } \\
\text { articles }\end{array}$ & $\begin{array}{l}\text { Translated } \\
\text { articles }\end{array}$ & $\%$ & $\begin{array}{l}\text { Authors of the translated articles \& } \\
\text { translators }\end{array}$ \\
\hline Türk Derneği & 72 & 2 & $\approx 4$ & $\begin{array}{l}\text { 1. Vladimir Gordlevski - translator's } \\
\text { name is not indicated }{ }^{27}(\mathrm{III})^{28} \\
\text { 2. von Goethe }(\mathrm{VII})-\text { translator's }^{\prime} \\
\text { name is not indicated }\end{array}$ \\
\hline Genç Kalemler & 276 & 7 & $\approx 2$ & $\begin{array}{l}\text { 1. Anatole France - Kâzım Nami (II/1, } \\
\text { II/2, II/3, II/4, II/6, } \\
\text { 2. Fernard Gregh - A. Asfer (II/3, II/7) } \\
\text { 3. Gorki - Kaya Alp (II/10) } \\
\text { 4. No Author's name - A. Rifat (II/11) } \\
\text { 5. Andreyef - Kaya Alp (II/12, II/14, } \\
\text { II/15, III/4, III/11 } \\
\text { 6. Jules Renard - M. Şekip (III/4, } \\
\text { IV/1-2,) } \\
\text { 7. Theodor Petrovik (?) })^{29}(\mathrm{III} / 4) \text { - } \\
\text { translator's name is not indicated }\end{array}$ \\
\hline Türk Yurdu & 709 & 10 & $\approx 7$ & $\begin{array}{l}\text { 1. von Le Coq - Saffet }(1 / 3 \text {, } \\
\text { 2. von Le Coq } I / 4, \text { - translator's name } \\
\text { is not indicated } \\
\text { 3. von Le Coq (I/8, I/9, I/10, I/II) - } \\
\text { translator's name is not indicated } \\
\text { 4. Clovis Hooke (?) - Ahmet Cevat } \\
\text { (I/10) } \\
\text { 5. Ahmet Hikmet - Akçuraoğlu } \\
\text { 6. P. Risal - T.Y. (II/9, II/10, II/11, } \\
\text { II/12, III/1, III/2, III/3, III/4 } \\
\text { 7. Pierre Loti - Hamdullah Suphi } \\
\text { 8. Şeyh Cemalettin Efgani - Resulzade } \\
\text { Mehmet Emin } \\
\text { 9. Cemalettin Efgani - Resulzade } \\
\text { Mehmet Emin } \\
\text { 10. Anna Astil - Halide Edip }\end{array}$ \\
\hline İslâm Mecmuast & 358 & 2 & $\approx 0,6$ & $\begin{array}{l}\text { 1. Gustave Le Bon - translator's name } \\
\text { is not indicated ( } 3 \text { ) } \\
\text { 2. Lord Hydeley (?) - translator's name } \\
\text { is not indicated (9) }\end{array}$ \\
\hline
\end{tabular}

\section{Appendix 2 - Dictionaries used in the research}

Monolingual and Etymological Dictionaries

Ayverdi, İlhan (2008): Kubbelatı Lugatı Misalli Büyük Türkçe Sözlük [Kubbealtı Turkish Dictionary]. Istanbul: Kubbealt1.

DevellioĞLu, Ferit (1964): Osmanlica - Türkçe Okul ve Yazışma Sözlüğü [Ottoman-Turkish School and Correspondence Dictionary]. Ankara: Doğuş Ltd. Şti. Matbaası, Ankara.

Devellıŏ̆Lu, Ferit (2003): Osmanlıca-Türkçe Ansiklopedik Lugat [Ottoman-Turkish Dictionary]. Ankara: Aydın Kitabevi Yayınları.

Eу ̈̈воĞLU, İsmet Zeyi (2004): Türk Dilinin Etimoloji Sözlüğü [Etymological Dictionary of the Turkish Language]. Istanbul: Sosyal Yayınları.

NişAnyan, Sevan (2007): Sözlerin Soyacağı Çağdaş Türkçenin Etimolojik Sözlüğü [The Genealogy of the Words Etymological Dictionary of Contemporary Turkish]. Istanbul: Adam.

ÖzöN, Mustafa Nihat (1987): Osmanlıca Türkçe Sözlük [Ottoman Turkish Dictionary]. Ankara: İnkilap Yayınları. 
SAMI, Şemsettin (1934): Kamus-i Türki [Etymological Dictionary of the Turkish Language]. Tarama Dergisi. Ankara: TDK.

Tietze, Andreas (2002): Tarihi ve Etimolojik Türkiye Türkçesi Lugatı Sprachgeschichtliches und etymologisches Wörterbuch des Türkei-Türkischen [Historical and Etymological Dictionary of the Turkish Language in Turkey]. Volume 1 A-E. Istanbul/Wien: Simurg/Österreichische Akademie der Wissenschaften.

Osmanlica Türkçe Sözlük [Ottoman-Turkish Dictionary]: Visited on 16 April 2014, <http://www. osmanlicaturkce.com>.

\section{Bilingual Dictionaries}

Avery, Robert, Bezmez, Serap, Edmonds, Anna, G. et al., eds. (1998): Redhouse İngilizce Türkçe Sözlük [Redhouse English-Turkish Dictionary]. Istanbul: Sev Matbaacılık ve Yayıncılık A.Ş. SAMI, Şemsettin (1905): Dictionnaire Français-Turc. Constantinople: Mihran.

SARaç, Tahsin (1989): Büyük Fransızca-Türkçe Sözlük: Grand Dictionnaire Français-Turc. Istanbul: Adam.

Steuerwald, Karl (1988): Almanca Türkçe Sözlük [German Turkish Dictionary]. Wiesbaden/ Istanbul: Otto Harrasowitz Verlag/ABC Kitabevi A.Ş. 